This PDF is a selection from an out-of-print volume from the National Bureau of Economic Research

Volume Title: The Transition in Eastern Europe, Volume 1

Volume Author/Editor: Olivier Jean Blanchard, Kenneth A. Froot, and Jeffrey D. Sachs, editors

Volume Publisher: University of Chicago Press

Volume ISBN: 0-226-05660-0

Volume URL: http://www.nber.org/books/blan94-2

Conference Date: February 26-29, 1992

Publication Date: January 1994

Chapter Title: Stabilization and Reform in Eastern Europe: A Preliminary Evaluation

Chapter Author: Michael Bruno

Chapter URL: http://www.nber.org/chapters/c6015

Chapter pages in book: (p. $19-50)$ 


\title{
Stabilization and Reform in Eastern Europe: A Preliminary Evaluation
}

\author{
Michael Bruno
}

The transformation of Eastern Europe from centrally planned to market economies provides an unprecedented challenge for policymakers in these countries as well as for the international community involved in financing and monitoring their economic programs. It also poses an unusual challenge for the economics profession because there is little prior experience on which to draw for lessons that could be applied to the present context. ${ }^{1}$

According to the customary classification, the East European countries belong to the group of middle-income countries. Their relative income levels (with suitable correction of relative prices), past growth rates, levels of education, and health all put them in this class. Their political and economic crisis came in the wake of increasing maladjustment of the whole ex-Soviet bloc to the changing world growth and trade environment. In that superficial respect, the adjustment and structural reform problems of Eastern Europe would seem to be akin to those of other middle-income countries, such as Brazil, Mexico, or Israel; these countries had enjoyed long periods of growth and relative price stability in the past, but in the course of the 1970 s and 1980 s they underwent severe structural crises that were either exacerbated or caused by poor response to external shocks such as the oil and debt crises. The delayed effects of some

Reprinted with permission from IMF Staff Papers 39:4 (December 1992), (C) 1992 International Monetary Fund.

This paper was written while the author was a visiting professor at the Massachusetts Institute of Technology and a visiting scholar in the International Monetary Fund's Research Department. He wishes to thank Massimo Russo and Michael Deppler for initiating this study and many members of both the European I and the Research departments for helpful discussions and comments on earlier drafts. He is likewise grateful to Olivier Blanchard, Mario Blejer, Kemal Derviş, David Lipton, Stanley Fischer, and Hans Schmitt.

1. Hungary started its reform process at an earlier stage, and some of the lessons from this experience are of considerable importance. However, the scope of the reform in the other four countries and the speed with which it was initiated have no precedent in a command economy. 
of these same shocks (e.g., energy and raw material prices) are only now being felt in Eastern Europe. The difference, however, is not only one of timing or of degree. Here, it is the whole political and economic framework that has collapsed. Far-reaching political reform was followed by the adoption of an economic reform the desired end product of which was similar to that of other middle-income countries, but the distance between the initial point and the desired goal is not only wider but also substantially deeper.

The present discussion is confined mainly to the lessons that can be learned from the aftermath of stabilization and price reform programs adopted in five East European countries-Hungary, Poland, the Czech and Slovak Republics, Bulgaria, and Romania-in 1990 and 1991. By this stage, some institutional reforms had already begun to take effect, such as the breakup of the monobank into separate central bank and commercial banking systems. Privatization, however, was only in the early legislation stage.

How similar are the aims of the reform in Eastern Europe to other recent efforts? One similarity is the attempt to reform and adapt the economic structure for integration into the world economy, which involves opening up the economy and moving from a completely controlled and distorted set of relative prices to relative world prices (for tradable goods). Another similar aim is macroeconomic stabilization, which has to do with the price level as well as internal and external balances. Stabilization, in turn, implies the elimination of high inflation or hyperinflation, which either already exists or is repressed (by open budget deficits, or soft budget constraints, or monetary overhang) and is bound to erupt once prices are decontrolled. Thus far, the objectives (and even the means of attaining them) are quite similar to those in other reforms (consider, e.g., the recent Mexican reform comprising simultaneous stabilization and opening up).

The chief novelty in the East European experience is the revolutionary change that is required in the institutional infrastructure-the financial system (such as the breakup of a monobank system), the fiscal,structure, social safety nets, the establishment of private property rights, and the mass privatization effort. One could easily point to many noncentrally planned economies that have either soft budget constraints, a financially repressed business sector, or highly subsidized state enterprises, or some combination of all three. However, their underlying structure is nonetheless market oriented, and private property rights are reasonably well defined. Although a lot can be learned from the reforms that have been applied to the distorted subsystems in these other countries, there is a sea of difference between them and those countries where the whole economy is one centrally controlled, nonmarket, publicly owned and financed system, with no other normative internal reference point, and a market economy has to be created where none had existed before. These circumstances have dictated a more comprehensive approach to the reform process than has ever been adopted to date.

All the reform plans, which were part of International Monetary Fund (IMF) 
programs, recognized that a simultaneous assault on macroeconomic stabilization, prices, and property rights was necessary from the inception stage of these programs. ${ }^{2}$ The programs have been largely "heterodox" in their approach to price stabilization, although they have differed from their predecessors (e.g., Israel and Mexico) in several respects, such as the way in which wages were controlled. But the programs have been much more far reaching and ambitious in their attempt to move at great speed from the initial production equilibrium of the old system to the desired new market-based structure.

The initial stabilization results have been impressive by and large, even though the initial price shock in all countries was larger than expected, leading, in most cases, to persistent inflation. Likewise, the observed balance-ofpayments improvements may in some cases turn out to be transitory. The main surprise for policymakers, and the major departure from the IMF's initial forecasts, was the speed with which the old productive system responded to the new price and incentive signals. The collapse of the Council for Mutual Economic Assistance (CMEA), which, in a sense, was an exogenous event from the point of view of each country, had disastrous consequences on output in almost all countries; but this is probably not the whole story. While a private, small enterprise sector was developing, both demand and supply factors played a much larger than expected role in sharply contracting the output of the large state-owned enterprises (SOEs). Although some of this contraction may be endemic to the process of stabilization, in virtually all cases the more problematic issues were the slow tempo of structural adjustment and the sluggishness of the privatization effort.

Although this paper addresses issues common to all the countries involved, one should not ignore differences in performance, some of which originate from the considerable diversity in initial conditions that the countries faced at the start of the present reform process. Section 1.1 begins with a brief survey of these initial conditions as well as a general outline of the IMF-supported programs. ${ }^{3}$ Section 1.2 follows with a general discussion of the concept of economic reform, based on previous experience with relative speeds of adjustment in different markets and spheres of economic behavior. A distinction is drawn between stabilization of prices and exchange rates, which can be achieved fairly rapidly, and the responses of production structure, investment, and ownership patterns to sharp changes in relative prices, all of which tend to be extremely slow. Market failure may indeed persist for a long time, which

2. It is important to point out that, unlike many past cases, IMF programs in East European economies thus far have typically been self-imposed, drastic adjustment programs, to which the IMF has given its blessing rather than having been the primary initiator. (For comparative details of MF programs in Eastern Europe, see table 1.2 below).

3. A more detailed discussion of developments in each country can be found in individual country surveys published by the Organization for Economic Cooperation and Development (OECD) and the IMF (Demekas and Khan 1991; and Aghevli, Borensztein, and van der Willigen 1992). See also the papers by Derviş and Condon (on Hungary), Berg and Blanchard (on Poland), and Dyba and Svejnar (on Czechoslovakia) in this volume. 
raises the vexing issues of sequencing and the need for, or extent of, residual government involvement in the transition stage.

Price overshooting and the output collapse, and their relation to the choice of policies, are taken up in sections 1.3 and 1.4, respectively. Section 1.5 discusses the fiscal balance and, in particular, its sustainability in view of the inevitable erosion of the state enterprise tax base and persistent pressures for additional social expenditures (replacing the old subsidies). Section 1.6 addresses the problems of financial reform, bad loan portfolios, interenterprise credit arrears, and the need for a major cleanup and capitalization of the weak commercial banking sector. Section 1.7 raises the question of interim production, trade, and financial regimes for the state enterprise sector during the uncertain ownership and control period. Section 1.8 offers concluding remarks.

\subsection{Initial Conditions and Country Programs}

Although almost all the countries in question had embarked on partial structural reform in the 1960s, only in Hungary did these reforms not subsequently grind to a halt. Although the reform process in Hungary was gradual and beset by many setbacks, it persisted over a period of twenty years, and, even though the objective of that reform was not a market-based economy, Hungary emerged better prepared on the institutional economic front than the other countries for the dramatic political liberalizations of 1989-90. Reforms had already led to price and trade liberalizations ${ }^{4}$ and developments in the smallscale private ownership sector, and Hungary had also introduced a two-tier banking system, a tax reform, and a corporate law before 1989.

In Poland, which has always had a private agricultural sector, ${ }^{5}$ there were also some private-sector developments prior to 1989. Both countries, however, suffered from an initial external debt overhang (see table 1.1, which details initial preprogram conditions), and both showed practically no growth in the 1980s. Unlike Hungary, Poland's imbalance prior to 1989 was also internal, the result of a large monetary overhang that the partial price liberalizations and ensuing hyperinflation of 1989 helped eliminate, or at least reduce substantially, before the January 1990 program.

In the absence of an explicit measure of the monetary overhang, the estimate of the ratio of money to gross domestic product (GDP) (row 6 in table 1.1) gives a rough indication. If 0.4 can be considered the norm, there was no over-

4. By 1982 , over 50 percent of consumer goods were free of control, the percentage gradually increasing to 80 percent by 1990 and to over 90 percent in 1991 . Trade liberalization proceeded more slowly. On the Hungarian economic reform process since 1968, see Boote and Somogyi (1991). For a good account of the more recent economic developments, see the OECD survey on Hungary (OECD 1992).

5. Also, in Poland the weakening of state control had already started in 1981, with two Solidarity-induced laws that gave a measure of autonomy to firms and induced the beginning of a private sector outside agriculture. Poland's other institutional reforms, however, lagged behind Hungary's (see Lipton and Sachs 1991). 
Table 1.1

Eastern Europe: Initial Conditions

\begin{tabular}{|c|c|c|c|c|c|}
\hline Indicator & Hungary & Poland & Czechoslovakia & Bulgaria & Romania \\
\hline Population (in millions, mid-1989)a & 10.6 & 37.9 & 15.6 & 9.0 & 23.2 \\
\hline GNP per capita (in 1989 US \$) & 2,590 & 1,790 & 3,450 & 2,320 & 2,290 \\
\hline \multicolumn{6}{|l|}{$\begin{array}{l}\text { GNP growth (average annual rate, } \\
\text { in } \%, \text { at constant prices): }\end{array}$} \\
\hline 1970 s & 4.5 & 5.5 & 4.6 & 7.0 & 9.3 \\
\hline $1980 \mathrm{~s}$ & .5 & -.7 & 1.4 & 2.0 & 1.8 \\
\hline Administered prices (\% of total) & 15 & $100^{c}$ & 100 & 100 & 80 \\
\hline State ownership (\%) & 90 & 70 & $100^{d}$ & $100^{\circ}$ & $100^{d}$ \\
\hline Money (M2)/GDP (1990) & .4 & .9 & .7 & 1.3 & .6 \\
\hline External debt/GDP $(1990, \%)$ & 65 & 80 & 19 & 50 & 3 \\
\hline External debt-service ratio (1990) & $57^{r}$ & 56 & 23 & 116 & ${ }^{\circ}$ \\
\hline \multicolumn{6}{|l|}{ Exports to CMEA, 1990:8 } \\
\hline$\%$ of total exports & 43 & 41 & 60 & 69 & $\ldots$ \\
\hline$\%$ of GDP & 16 & 14 & 25 & 34 & $\ldots$ \\
\hline
\end{tabular}

aWorld Bank (1991); IMF staff estimate for Romanian GNP per capita. All these data are highly sensitive to the choice of exchange rates.

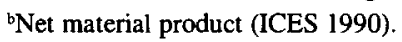

'Excluding food prices.

'Economy-wide.

'Economy-wide, except 15 percent of agriculture.

In percentage of merchandise exports.

${ }^{8}$ Estimates are tentative since they are very sensitive to distortions in intra-CMEA prices and exchange rates. Data for exports are based on estimated world market prices (considerably above the official traded prices); however, the GDP data are based on actual official prices. For Romania, export data are available only at official prices, which tend to underestimate the weight of CMEA trade; on this basis, CMEA exports were 39 percent of total exports and equivalent to 6 percent of GDP.

hang in Hungary at the start of the reform process; it was large in Poland (in 1989 and probably even larger before 1989) and Bulgaria and smaller in Czechoslovakia and Romania.

It is interesting that, during the twenty years following the spring of 1968 , Czechoslovakia reverted to the most orthodox centrally planned economy (see table 1.1) and was thus, in a structural sense, much less prepared for the big change. Yet, on the eve of the January 1991 reform, not only did Czechoslovakia enjoy the most favorable initial internal and external macroeconomic balance, but it also had only a small monetary overhang and an extremely low ratio of external debt to gross national product (GNP). ${ }^{6}$

6. In an interesting recounting of economic developments in these countries in the preCommunist era (Solimano 1991), Czechoslovakia stands out as having had a prudent macroeconomic tradition. It also had the most developed industrial structure by the time communism took over. Major subsequent development took place in Slovakia, which has undoubtedly had repercussions on Czechoslovakia's present structural reform process and interrepublican political and social problems. 
Bulgaria had the most extensive industrial development in relation to its starting point (with some 60 percent of the labor force in that sector, compared to a mere 20 percent in the 1930s), much of it confined to exports to the former Soviet Union (see row 9 in table 1.1). In the years since 1985, Bulgaria incurred a sizable external debt as its foreign finances faltered, and the country faced a severe foreign exchange constraint by the time the reform started as well as a substantial monetary overhang. Romania, which had no external debt at all and was less dependent on CMEA trade, was nonetheless plagued by severe internal economic, social, and political problems, on top of specific supply problems in the oil market.

At the beginning of 1991, three of the countries-Czechoslovakia, Bulgaria, and Romania-adopted programs that essentially resembled the Polish program of 1990. (For a comparison of programs, see table 1.2.) The main breakaway from their past was an almost complete price liberalization and a substantial elimination of price subsidies, with the aim of achieving fiscal balance, coupled with the establishment of strict monetary targets and wage ceilings. The choice of exchange rate regime differed, with Czechoslovakia, like Poland in 1990, adopting a peg as a nominal anchor (after several devaluations in the preceding months, which almost doubled the exchange rate). Lacking foreign exchange reserves, Bulgaria and Romania both floated and let the interbank market determine a considerably depreciated exchange rate, thereby tripling the previous official rate (fig. 1.1), although the phasing in of the exchange rate reform was more gradual in Romania. In all four countries, the external reform program included substantial trade liberalization with current account convertibility and other measures and institutional changes pertaining to structural adjustment and privatization.

Hungary adopted a gradualist program in January 1991, involving a much smaller devaluation (15 percent), a further liberalization of prices (up to 90 percent of the consumer basket by the end of 1991, a considerable stepping up of the previous gradual move from 56 percent in 1985), and restrictive fiscal, monetary, and incomes policies. The program, which was more ambitious than previous programs, also included a substantial further liberalization of imports and another set of structural adjustment and privatization measures. ${ }^{7}$

The programs for Poland, Czechoslovakia, Bulgaria, and Romania were obviously conceived as "big bang" moves. The underlying theme was that, with few exceptions, the price and trade systems had to be liberalized all at once under the umbrella of fiscal, monetary, and incomes restraint. At the same time, new financial institutions were being put in place, and the productive systems were slated for rapid privatization so as to minimize the uncertainties of operation under public ownership and controls.

7. The average tariff dropped from 18 percent in 1985 to 16 percent during $1986-89$ and to 13 percent in 1991. The share of imports liberalized rose from 0 to 16 percent in 1989 and 37 percent in 1990 , to reach 72 percent in 1991 (see Derviş and Condon, in this volume). 


\begin{tabular}{|c|c|c|c|c|c|}
\hline Indicator & Hungary & Poland & Czechoslovakia & Bulgaria & Romania \\
\hline Date & 20 February 1991 & 5 February 1990 & 7 January 1991 & 15 March 1991 & 11 April 1991 \\
\hline Length & 36 months & 13 months & 14 months & 12 months & 12 months \\
\hline Exchange system & $\begin{array}{l}15 \% \text { devaluation in } \\
\text { January, then managed }\end{array}$ & $\begin{array}{l}\text { Initial sizable } \\
\text { devaluations, then fixed }\end{array}$ & $\begin{array}{l}35 \% \text { devaluation in } \\
\text { October, 1990; } 15 \% \\
\text { devaluation and } \\
\text { unification with tourist } \\
\text { rate in December } 1990 ; \\
\text { then fixed }\end{array}$ & Floating interbank & $\begin{array}{l}\text { Official rate fixed; } \\
\text { floating interbank } \\
\text { Convergence of official } \\
\text { and interbank }\end{array}$ \\
\hline Wages & Tax-based incomes policy & Tax-based incomes policy & Tax-based incomes policy & $\begin{array}{l}\text { Real wage cut by } 35 \% \text {, } \\
\text { implemented by } \\
\text { ceilings on wage } \\
\text { bills }\end{array}$ & Tax-based incomes policy \\
\hline Interest rates & $\begin{array}{l}\text { With abolition of interest } \\
\text { rate ceilings will be } \\
\text { market based }\end{array}$ & $\begin{array}{l}\text { Establish positive real } \\
\text { interest rates }\end{array}$ & $\begin{array}{l}\text { Increase before program } \\
\text { and flexible } \\
\text { management thereafter }\end{array}$ & $\begin{array}{l}\text { Very large increase } \\
\text { before program; } \\
\text { flexible adjustment } \\
\text { thereafter }\end{array}$ & $\begin{array}{l}\text { Complete liberalization; } \\
\text { CDs with flexible rates }\end{array}$ \\
\hline Privatization & Continue in 1991 & Continue in 1991 & Start in 1991 & Start in 1991 & Start in 1991 \\
\hline $\begin{array}{l}\text { Two-tier banking } \\
\text { system }^{\mathrm{a}}\end{array}$ & 1987 & 1990 & 1990 & 1989 & 1990 \\
\hline
\end{tabular}

aThe establishment of a two-tier banking system ended direct central bank involvement in commercial banking. 

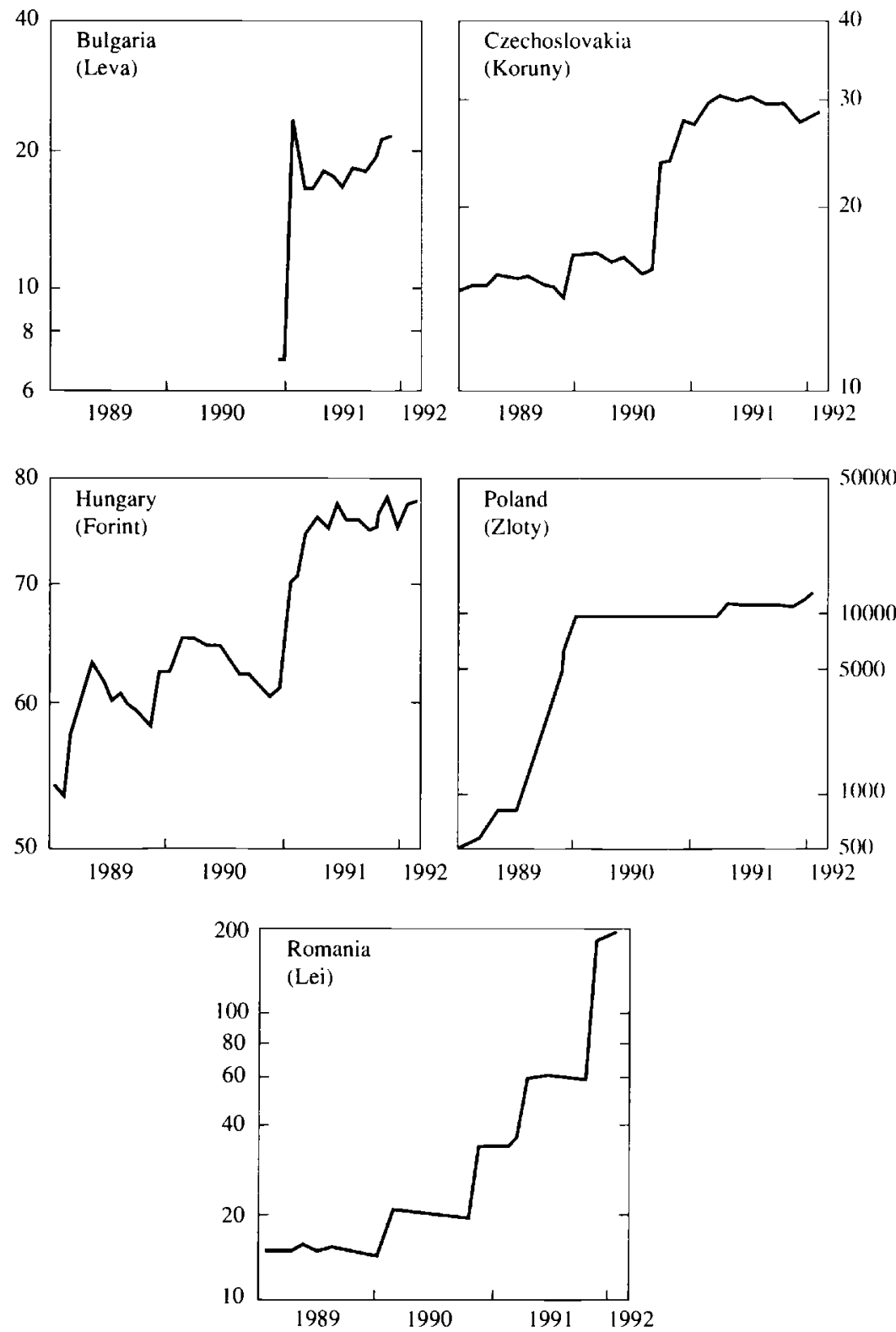

Fig. 1.1 Exchange rates, 1989-92 (end of period: local currency/U.S. dollar, in log scale)

Sources: National authorities and IMF staff estimates. 
In all five countries, the initial price liberalization was expected to involve a substantial price shock, to be followed a few months later by relative price stability. The actual results are discussed in section 1.3.

\subsection{Concepts of Economic Reform-Big Bang and Gradualism}

The key question that has to be asked at the outset of any major reform process is whether to adopt the big bang approach or gradualism in the move from the distorted equilibrium of the prereform period to the desired new quasi equilibrium. The answer to this question is not at all clear. Cumulative experience from hyperinflation and high-inflation episodes (say, at least three-digit annual inflation rates) points only to the clear advantage of the big bang approach at the inflation stabilization stage (recent successes have been Bolivia, Mexico, and Israel). ${ }^{8}$

In the recent successful stabilizations in Israel and Mexico, credibility, expectation signaling, and the problem of nominal synchronization (i.e., avoiding sharp changes in relative prices) dictated a multiple anchor or "heterodox" approach. The initial hyperinflation outburst prompted Poland and Yugoslavia to follow this approach in the 1989-90 stabilizations. Czechoslovakia, Bulgaria, and Romania also chose a big bang approach in 1991, even though their inflation rates were relatively low. ${ }^{9}$ Given the repressed prereform system, the potential for inflationary outburst may have justified their choice, which enabled them to avoid the hyperinflation that would have erupted in the price liberalization stage in the absence of tight macro policies.

These choices, however, apply only to price stabilization and the achievement of initial internal and external balance. There still remains the question of how much and how fast one should go on a broader reform front. For example, do trade liberalization and a move to convertibility, let alone privatization, necessarily require a big bang approach? The answer is much less clear ex ante and is even less clear given the results. Trade liberalization, for example, can give the right long-term signal from the start, but its execution could, in principle, be gradual. (This question will be taken up in the discussion of output collapse in sec. 1.3.) Similar examples in either direction can be cited, such as the opening up of internal and external financial and capital markets. The United Kingdom opted to go cold turkey, while other European countries chose to move more gradually and nonetheless achieved their targets. Israel applied shock therapy to inflation but opened up its financial, capital, and for-

8. Chile's 1970 stabilization is the only successful example of the gradualist approach (the trade liberalization, interestingly enough, was done relatively quickly). The social cost, however, was extremely high, and the strategy would probably not be feasible in an open democracy. For a comparative analysis of the stabilization and reform experience in Latin America and Israel, see Bruno (1993). Fischer and Gelb (1990) were among the first to discuss the phases of reform for Eastern Europe.

9. Hungary could afford gradualism because, as noted earlier, its opening up and structural reform process had been going on for much longer-in a sense, since 1968. 
eign exchange markets gradually (as it successfully did with trade liberalization in the 1960s).

A closely related issue is the speed of adjustment of markets to changes in signals and the credibility that agents attach to announced signals of future market environments that are not yet evident in today's markets. It is well known that the speed of adjustment in asset markets is extremely high; the response is often instantaneous because the adjustment costs are low. However, adjustment in commodity and labor markets, let alone the production response that follows from new investment, is considerably slower, often lasting three or four years. Any reform such as privatization of large-scale enterprises or the introduction for the first time of a value-added or income tax that requires complicated legislation, the introduction of new accounting procedures, and new implementation or monitoring mechanisms may take at least as long as that.

It is important to stress that these long adjustment lags do not occur solely in hitherto centrally planned economies. Structural adjustment is a slow process even in the most advanced market-based economy - even when the reform is credible. This was true of the reconstruction effort in Europe after World War II and of structural adjustment efforts following on a successful major stabilization (such as in Israel in the wake of the 1985 stabilization). Even in a country like Finland, the collapse of the CMEA caused a substantial drop in GDP. In all these cases, adjustment was or will be prolonged, even though the underlying structure is market based.

Therefore, the advocate of a big bang has to make clear which particular portion of the policy package is implied. Also, the argument for a big bang beginning may rest on a special political opportunity, as in Poland. But there may also be an intertemporal political trade-off: overly costly programs might lead to political reversal at a later stage, as "adjustment fatigue" sets in or social aspirations, such as employment opportunities and living standards, are frustrated. Have policymakers sufficiently considered these questions at the inception stage of the program?

It is not clear whether there were any illusions about the length of time it would take the East European economies to attain the competitive market structure, private ownership, and properly functioning financial system of a typical Western economy. But there seems to have been overoptimism at the onset of the programs about the speed of the supply response and other behavioral responses that could come in the wake of a drastic change in the economic environment.

\subsection{Stabilization: Was the Initial Price Shock Necessary?}

In all cases except Hungary, the initial price shock turned out to be substantially larger than expected, but, within six months of the program, inflation came down to less than 2-3 percent a month in Poland, Czechoslovakia, and 
Hungary. Inflation edged up, after a temporary drop, to an average monthly rate of 4-5 percent in Bulgaria and 10 percent in Romania (see averages in table 1.3 and monthly data in table 1.4 and fig. 1.2). However, by the end of 1991, only Czechoslovakia and Hungary were running annual rates of inflation below 20 percent, ${ }^{10}$ or a monthly rate of less than 1.5 percent, while Poland's rate has been running at least twice as high (about 3.0-3.5 percent a month, or 40 percent a year). The Czechoslovak stabilization was virtually a textbook case-the initial price shock was followed by price stability throughout most of the second half of 1991 (fig. 1.2 and table 1.4).

Differences in initial conditions no doubt played an important role. Poland started its program in the midst of a hyperinflation caused by a series of price hikes that may or may not have eliminated the monetary overhang by January 1990 (this issue is in dispute). At any rate, a 45 percent price shock was forecast for January 1990, but the actual outcome was 80 percent (for January and February together; the respective figures are 67 percent forecast and 122 percent actual). During the whole of 1990 , inflation was expected to be less than 100 percent and ended up at about 250 percent; thus, even the residual inflation, after the initial shock, turned out to be higher than planned.

For Czechoslovakia, which started from a stable price level and a considerably smaller monetary overhang, a price increase of only 25 percent was forecast. The actual increase was 40 percent in the first quarter of 1991, a smaller relative discrepancy than Poland's. Moreover, the residual inflation in Czechoslovakia during the first year was only 10 percentage points higher than expected, after allowing for the first quarter's shock.

Both Bulgaria and Romania started off from a much worse initial position and made a number of additional price corrections during the year, so it is probably too early to pass judgment on the success of the initial move, particularly for Romania. The sharp foreign exchange shortage in these two countries, which necessitated the adoption of a different exchange rate regime at the start and a considerably larger initial exchange rate hike, may also account for the worse subsequent inflation profile. As in other aspects, Hungary was an outlier. Its initial price shock was small, 10 percent, as expected, and its residual inflation also hit the target (table 1.3).

Three questions arise in the face of these initial price developments, after due consideration is taken of the fact that price comparisons between a postliberalization system and a distorted and rationed preliberalization stage impart a considerable upward bias to the data. ${ }^{11}$ Why was the price shock in most cases so much higher than expected? What are the implications of the initial shock for the subsequent inflation profile (the implications for the real system will be discussed later)? Was an initial price shock as large as Poland's necessary?

10. This is a convenient reference point because it corresponds to recent inflation rates in the successful stabilizers of high inflation-Bolivia, Chile, Israel, and Mexico (see Bruno 1993).

11. An interesting question is whether different initial conditions in the various countries might have led to different relative biases in these price shock estimates. 
Table 1.3

Eastern Europe: Selected Indicators, 1990-91

\begin{tabular}{|c|c|c|c|c|c|c|c|c|}
\hline Program/Actual & GDPa,b & $\begin{array}{c}\text { Consumer } \\
\text { Prices }^{\mathrm{e}}\end{array}$ & $\begin{array}{c}\text { Nominal } \\
\text { Wage }^{c}\end{array}$ & $\begin{array}{l}\text { Broad } \\
\text { Money }^{\mathrm{c}}\end{array}$ & $\begin{array}{c}\text { Budget } \\
\text { Balance }^{\mathrm{d} e}\end{array}$ & $\begin{array}{c}\text { Convertible } \\
\text { Current } \\
\text { Account }\end{array}$ & $\begin{array}{c}\text { Convertible } \\
\text { Current } \\
\text { Account }^{f}\end{array}$ & $\begin{array}{c}\text { Total } \\
\text { Exports }^{i, g}\end{array}$ \\
\hline \multicolumn{9}{|l|}{ Hungary } \\
\hline 1990 actual & -4 & 33 & 23 & 29 & -.1 & .4 & .1 & 8.9 \\
\hline 1991 program & -3 & 31 & $\ldots$ & 23 & -1.5 & -3.6 & -1.2 & 12.6 \\
\hline 1991 actual & $\begin{array}{c}-8 \\
(-8)\end{array}$ & 32 & 20 & 29 & -4.1 & 1.0 & .3 & 9.6 \\
\hline \multicolumn{9}{|l|}{ Poland } \\
\hline 1989 actual & $\ldots$ & 640 & 472 & 236 & -7.4 & -2.7 & -1.8 & 8.1 \\
\hline 1990 program & -5 & 94 & $\ldots$ & 87 & -.1 & $\ldots$ & -3.0 & $\ldots$ \\
\hline 1990 actual & -12 & 249 & 160 & 122 & 3.5 & 1.3 & .7 & 15.0 \\
\hline 1991 program & 3 & 36 & $\ldots$ & 43 & -.6 & -2.7 & -2.7 & $\ldots$ \\
\hline 1991 actual & $\begin{array}{c}-8 \\
(-4)\end{array}$ & 60 & 54 & 49 & -7.2 & -2.9 & -2.2 & 13.2 \\
\hline \multicolumn{9}{|l|}{ Czechoslovakia } \\
\hline 1990 actual & $\ldots$ & 18 & 8 & 1 & -.3 & -2.4 & -1.1 & 11.6 \\
\hline 1991 program & -5 & 30 & 17 & 6 & .8 & -7.1 & -2.5 & 12.6 \\
\hline 1991 actual & $\begin{array}{l}-16 \\
(-9)\end{array}$ & 54 & 14 & 27 & -2.1 & .7 & .2 & 10.9 \\
\hline \multicolumn{9}{|l|}{ Bulgaria } \\
\hline 1990 actual & -12 & 64 & 32 & 12 & -9.2 & -16.1 & -1.2 & 5.7 \\
\hline 1991 program & -11 & 234 & 146 & 24 & .1 & $\ldots$ & -2.0 & 6.6 \\
\hline 1991 actual & $\begin{array}{c}-23 \\
(-16)\end{array}$ & 339 & 142 & 25 & -3.7 & -11.8 & -.9 & 3.7 \\
\hline \multicolumn{9}{|l|}{ Romania } \\
\hline 1990 actual & -7 & 5 & 11 & 17 & -.5 & -8.0 & -1.7 & 5.8 \\
\hline 1991 program & $\ldots$ & 104 & $\ldots$ & 15 & -1.5 & $\ldots$ & -1.7 & 5.4 \\
\hline 1991 estimate & $\begin{array}{c}-12 \\
(-10)\end{array}$ & 223 & 124 & 66 & -3.0 & -6.6 & -1.3 & 3.5 \\
\hline
\end{tabular}

-Figures in parentheses provide an estimate of the fall of GDP owing to the fall in exports; percentage point contribution of the change in total exports to the percentage change in GDP.

'Figures given in terms of percentage change.

cFigures given in terms of year-end percentage change.

${ }^{\mathrm{d}}$ For Poland, general government balance; for Czechoslovakia, central and local government, extrabudgetary funds, excluding takeover of export credits, and transfers to the banks and foreign trade organizations on account of devaluation profits and losses; for Bulgaria, based on actual external debt service payments; for 1991, after external debt rescheduling and debt referral.

'Figures given in terms of percentage of GDP.

Including transactions in nonconvertible currencies.

BFigures given in billions of U.S. dollars. 
Table 1.4 Eastern Europe: Monthly CPI Inflation Rates, 1989-91 (\%)

\begin{tabular}{|c|c|c|c|c|c|}
\hline & Bulgaria & Czechoslovakia ${ }^{a}$ & Hungary & Poland & Romania \\
\hline \multicolumn{6}{|l|}{1989} \\
\hline Jan. & $\ldots$ & $\ldots$ & 4.5 & 11.0 & $\ldots$ \\
\hline Feb. & $\ldots$ & $\ldots$ & 3.4 & 7.9 & $\ldots$ \\
\hline Mar. & $\ldots$ & $\ldots$ & 1.0 & 8.1 & $\ldots$ \\
\hline Apr. & $\ldots$ & $\ldots$ & 1.7 & 9.8 & $\ldots$ \\
\hline May & $\ldots$ & $\ldots$ & .5 & 7.2 & $\ldots$ \\
\hline Jun. & $\ldots$ & $\ldots$ & .4 & 6.1 & $\ldots$ \\
\hline July & $\ldots$ & $\ldots$ & 2.1 & 9.5 & $\ldots$ \\
\hline Aug. & $\ldots$ & $\ldots$ & .3 & 39.5 & $\ldots$ \\
\hline Sep. & $\ldots$ & $\ldots$ & 1.0 & 34.3 & $\ldots$ \\
\hline Oct. & $\ldots$ & $\ldots$ & 1.1 & 54.8 & $\ldots$ \\
\hline Nov. & $\ldots$ & $\ldots$ & .7 & 22.4 & $\ldots$ \\
\hline Dec. & $\ldots$ & $\cdots$ & .8 & 17.7 & $\cdots$ \\
\hline \multicolumn{6}{|l|}{1990} \\
\hline Jan. & $\ldots$ & $\ldots$ & 7.7 & 79.6 & $\ldots$ \\
\hline Feb. & $\ldots$ & $\ldots$ & 5.3 & 23.8 & $\ldots$ \\
\hline Mar. & $\ldots$ & $\ldots$ & 2.7 & 4.3 & $\ldots$ \\
\hline Apr. & $\ldots$ & $\ldots$ & 2.5 & 7.5 & $\ldots$ \\
\hline May & $\ldots$ & $\ldots$ & .8 & 4.6 & $\ldots$ \\
\hline Jun. & 3.5 & $\ldots$ & .4 & 3.4 & $\ldots$ \\
\hline July & 3.6 & 10.0 & 2.6 & 3.6 & $\ldots$ \\
\hline Aug. & 16.3 & $\ldots$ & 2.9 & 1.8 & $\ldots$ \\
\hline Sep. & 4.5 & $\ldots$ & 1.5 & 4.5 & $\ldots$ \\
\hline Oct. & 4.2 & 3.4 & 1.5 & 5.7 & $\ldots$ \\
\hline Nov. & 5.3 & .8 & 2.1 & 5.0 & 23.4 \\
\hline Dec. & 10.2 & .8 & 1.7 & 5.9 & 11.6 \\
\hline \multicolumn{6}{|l|}{1991} \\
\hline Jan. & 13.6 & 25.8 & 7.5 & 12.7 & 14.8 \\
\hline Feb. & 105.2 & 7.0 & 4.9 & 6.7 & 7.0 \\
\hline Mar. & 32.7 & 4.7 & 3.7 & 4.5 & 6.6 \\
\hline Apr. & 1.8 & 2.0 & 2.4 & 2.7 & 26.5 \\
\hline May & 1.6 & 1.9 & 2.2 & 2.7 & 5.1 \\
\hline Jun. & 5.0 & 1.8 & 2.1 & 4.9 & 2.0 \\
\hline July & 7.9 & -.1 & .9 & .1 & 9.4 \\
\hline Aug. & 5.1 & $\ldots$ & .2 & .6 & 11.2 \\
\hline Sep. & 4.7 & .3 & 1.5 & 4.3 & 7.3 \\
\hline Oct. & 3.1 & -.1 & 1.3 & 3.2 & 10.4 \\
\hline Nov. & 3.5 & 1.6 & 1.4 & 3.2 & 10.4 \\
\hline Dec. & 3.1 & 1.2 & 1.7 & 3.1 & 13.7 \\
\hline
\end{tabular}

Sources: National authorities and IMF staff estimates.

"Rates from July-December 1990 are estimates from quarterly data. 

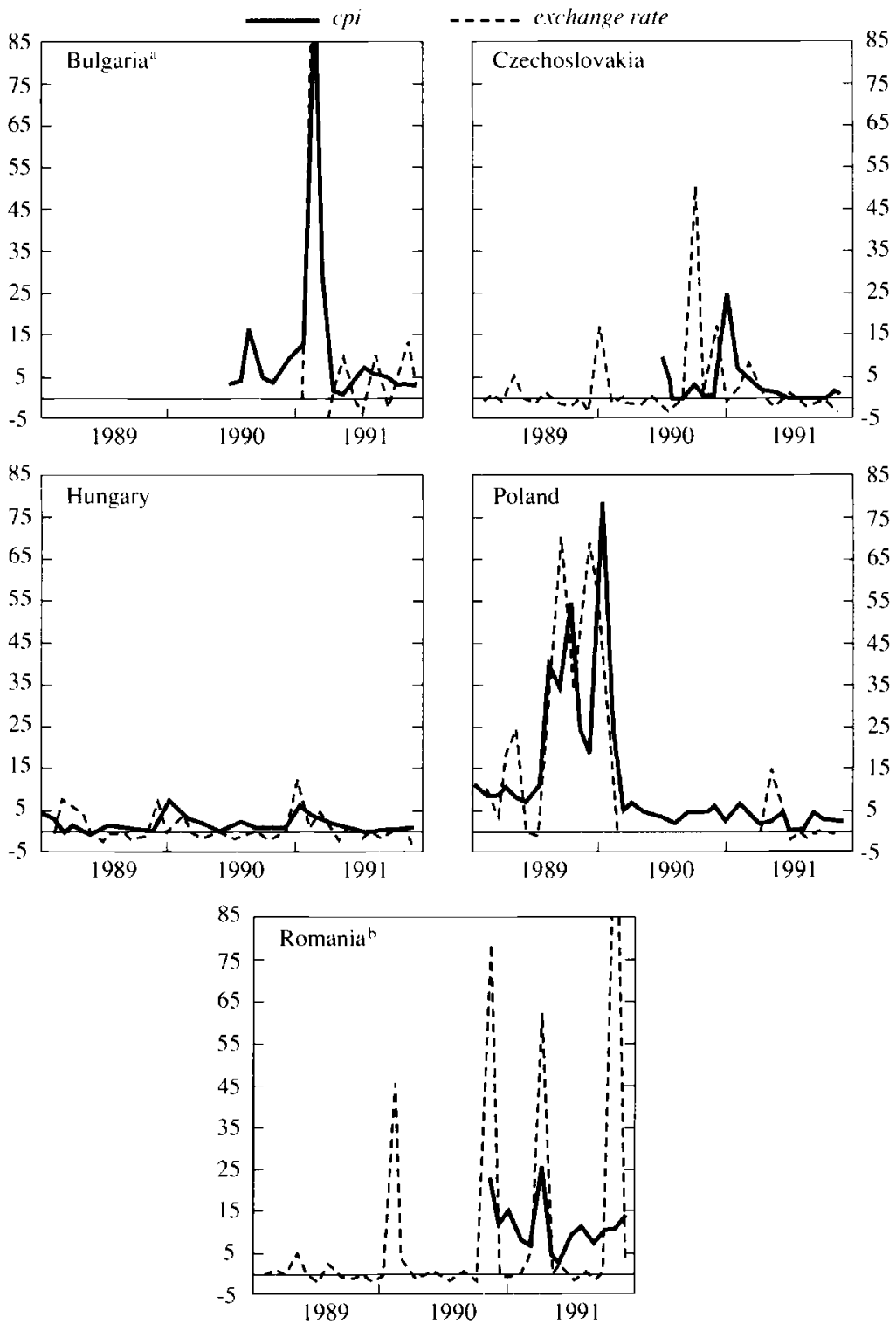

Fig. 1.2 CPI inflation and exchange rates, 1989-91 (monthly percentage change)

Sources: National authorities and IMF staff estimates.

a'CPI: February $1991=105.2$. Exchange rate: February $1991=247.1$, March $1991=30.5$.

${ }^{\mathrm{D}}$ Exchange rate: November $1991=204.84$ 
Possible sources of the unexpectedly high price level shocks include the existence of a larger unabsorbed monetary overhang, underprediction of the effects of a large initial devaluation, and monopolistic behavior on the part of state enterprises in anticipation of the imposition of price controls. In Bulgaria, and partly in Poland, the initial monetary overhang may have played a sizable role, whereas, in the other countries (in particular, Poland), the price response to the exchange rate devaluation alone or combined with other factors may have been responsible. Inflationary experience elsewhere has shown that the exchange rate, in the absence of another reliable measuring rod, often serves as the indicator to which pricing agents attach themselves, even when their product is not tradable. ${ }^{12}$

The answer to the second question about the relation of the initial shock to the subsequent inflation profile depends on whether the source of the shock is indeed confined to an existing monetary overhang. It would then follow that a higher initial price jump would "save" the system from additional inflationary adjustments later on, and there would thus be a positive trade-off between the initial shock and subsequent price stability.

If a monetary overhang is not the cause of the price shock, and if there is also a tendency for other nominal magnitudes in the system (money, credit, and wages) to "catch up" in line with their initial "planned" positions relative to the price level, then an initial price level discrepancy will also lead, through inertia, to higher than expected inflation. This may have been what happened in Poland and Bulgaria, but probably not, or less so, in Czechoslovakia. In the second half of 1990, money, credit, and wage ceilings were adjusted upward in Poland, and a similar correction was made in the second half of 1991 in Czechoslovakia and Bulgaria. In Poland, the difference between the actual wage and the wage ceiling in the earlier phase could be made up later, and enterprise managers availed themselves of this option, paying substantial additional taxes while doing so.

Hence, the third question: Was there an option of a smaller planned, or a smaller actual, price shock at the beginning? Technically, the answer is yes. Compare these programs to one successful heterodox predecessor: Israel in July 1985. With the substantial elimination of subsidies, Israel limited its initial price shock to 27 percent by opting for an attenuated devaluation (relative to what the fundamentals seemed to dictate) and introduced temporary price controls that were then gradually removed. However, there was obviously no monetary overhang, and the relative price levels were certainly not as distorted as those in the East European economies.

Yet it may be argued that Poland could have chosen a smaller devaluation up front and left price controls at a higher level for three months, say, and only

12. In Israel, this is called the dentist effect (because dentists raise their fees by the same rate at which the price of their material inputs rises, even though these inputs constitute only a small portion of the cost of treatment). 
then decontrolled completely, either all at once or gradually. ${ }^{13}$ But it could also be argued that, with distortions as big as they were and the new government's initial high credibility, it may have been just as well to "chop off the dog's tail all at once."

It is interesting that Czechoslovakia retained some control over its initial price shock through moral suasion and by stipulating maximum prices or trade margins on some key commodities and by requiring prior notification of price increases in some monopolistic sectors. Also, in Czechoslovakia and Bulgaria, certain price increases, such as for energy and housing, were delayed.

Do the initial benefits of a big price bang outweigh the subsequent costs of higher inertial inflation as well as other social costs? In pursuit of its devaluation and price liberalization goals, Poland was probably right in choosing to abolish price controls at the beginning, but it could have devalued by less and thus reduced the initial shock. The exchange rate may then have had to be realigned earlier than mid-1991, but the cumulative price increase over the two-year period could nonetheless have been smaller. For Bulgaria and Romania, the question arises whether they could afford to opt for a far-reaching relaxation of foreign exchange restrictions when the foreign exchange shortage was (and is) so extreme. One counterargument is that the administration of such restrictions would be ineffective.

Ending on a positive note-with all the quibbles afforded by hindsight duly noted - the overriding fact remains that in most of the cases far-reaching liberalization has been achieved, together with a reasonable measure of macroeconomic stability, in spite of a highly distorted starting point and immense economic and political risks. Finally, from the consumer's perspective, the qualitative change that has taken place in the market environment probably outweighs the statistical measure of price increase.

\subsection{Was the Output Collapse Unavoidable?}

There are several reasons for the large output fall. First of all, the anticipation of a sharp price increase stimulates hoarding, which is immediately followed by a substantial reduction in demand. Next, when prices rise by more than was planned while money, credit, and wages are kept within their specified nominal ceilings, the obvious result is a considerably larger than expected reduction in real money and credit as well as in real wages. This happened in Poland in 1990 and was repeated in the other countries that experienced shocks.

13. In the Polish case, in the initial absence of alternative inflation-immune financial assets, the free market exchange rate reflected a stock demand and far exceeded the relevant purchasing power parity exchange rate. This was the reason the authorities chose a smaller devaluation than initially planned. Ex post it may still have been too high-note that it took a year and a half of substantial inflation until the real appreciation of the exchange rate began to "bite" from a competitive point of view. 
How much of the output reduction, which was considerably larger than expected, can be directly linked to this price shock discrepancy? The results for the Polish program of 1990 show a considerable reduction in measured output, of around 12 percent, compared to a considerably lower forecast. ${ }^{14}$ Both the real wage squeeze and the real monetary squeeze certainly affected consumer demand and thus depressed output on the demand side.

The credit squeeze can also operate on the firm supply side if the financing of working capital is considered to be one of the factors of production (see Calvo and Coricelli 1992). Another channel through which the credit squeeze operates is the real interest rate if nominal interest rates are initially set at a level that is too high relative to the inflation rate that is expected after the initial price level shock. There is some evidence that the high initial real interest rate has in fact constrained firms more than the quantity of credit ${ }^{15}$ (to which they can and, in fact, did adjust through interfirm credit arrears). However, how much of the output decline, even in 1990, could be ascribed to this factor alone remains an open question.

\subsubsection{Supply-Side Shock}

In Poland, as well as in some of the other countries, there was a general shock on the supply-side, which can be termed a comprehensive management shock. Enterprise managers who were used to operating in a command environment where their "market" was assured and their financing accommodative suddenly had to make their own decisions in a completely transformed environment characterized by tremendous uncertainty. In these circumstances, the first natural impulse is to adopt a "wait and see" attitude, or to continue producing the old stuff for inventory, as long as there is working capital. Evidence points to unfulfilled credit ceilings in the first few months of the Polish, Czechoslovak, and Bulgarian programs, followed by a period in which credit ceilings were effective but wage ceilings were not reached. This situation was repeated during much of 1991 in the Bulgarian and Romanian programs. In Bulgaria and Romania (and, earlier, Czechoslovakia), the nominal interest rate was set at a level corresponding to the estimated postshock rate of inflation, rather than at a level that would ensure a positive real rate of interest in the first month. It is important to remember, however, that, in these three countries, unlike the Polish case, there was no preceding hyperinflation to contend with. Therefore, that a more moderate interest rate policy did not lead to an inflationary outburst is no proof that this policy should have been pursued in a hyperinflationary situation (such as Russia's).

It is important to remember that a credit crunch and high real interest rates

14. There is some doubt about the relevance of the -5 percent projected output drop. According to participants in the planning stage, this estimate had been arbitrary and was not based directly on any of the plan parameters.

15. This information comes from an unpublished World Bank report based on interviews in seventy-five state-owned enterprises in September 1991. 
are a universal problem in the immediate aftermath of sharp stabilizations (as was true for Bolivia, Mexico, and Israel). It could also be argued that the uncertainty about the outcome of stabilization justifies a highly contractionary monetary policy as a support for the exchange rate or wage anchors. Of the mistakes that can be made, it is better to err on the side of an overly restrictive stance. However, once initial success is achieved, a gradual, although careful, relaxation is called for.

\subsubsection{CMEA Collapse}

The collapse of the CMEA was another major contributor to the fall in output. Table 1.2 provides rough IMF staff estimates of that part of the output drop in 1991 that can be ascribed to the fall in exports caused by the demise of the CMEA. This estimate was based on the demand side, under the assumption of no short-run market substitutability (which obviously did not hold for Hungary or Czechoslovakia; see sec. 1.7). It did not explicitly take into account the very sharp terms of trade effect of the collapse, which was a substantial exogenous supply shock, much like the effect of the relative rise of energy and raw materials prices on the industrial countries in the 1970s and 1980s. It is interesting that, with the exception of Hungary, the implied unaccountable drop in output shown in table 1.3 seems to be correlated with the degree of prior dependence of the country on CMEA trade (table 1.1, row 9), which may be a proxy for the relative size of the potential terms of trade shock. ${ }^{16}$

The CMEA collapse caused the most damage in Bulgaria, the bulk of whose exports had gone to the CMEA. Bulgaria and also Romania, saddled by their foreign currency restraint, suffered severely from a lack of raw materials. ${ }^{17}$ The relatively larger fall in Poland's output in 1991 than seems warranted by its dependence on CMEA trade may have to do with the degree of rigidity in wages. In Poland, the real product wage did not continue to fall in 1991 but rather increased by 15 percent, thus exacerbating the effect on the terms of trade. At any rate, more detailed country studies of the components of the output collapse are needed before we can assess how big a margin needs to be explained over and above the effects of the CMEA collapse in 1991.

To what extent was this unprecedented output drop unavoidable? Even if it could not have been avoided, it is not clear whether other policies-such as structural adjustment policies and privatization-can facilitate a rebound in

16. A recent estimate by Rodrik (1992) of the trade shock in the former Soviet Union, which includes the effect on the terms of trade for Hungary, Poland, and Czechoslovakia, is remarkably close to the numbers appearing in the brackets in table 1.3, so they may include terms of trade effects after all. In any case, neither the IMF's nor Rodrik's estimates include Keynesian multiplier effects or the effect of aggregate supply curve shifts under wage rigidity (see Bruno and Sachs 1985).

17. This is a clear case in which the short-run marginal product of additional infusion of foreign capital inflow is very high. Given excess capacity in complementary factors of production, the marginal GDP product of foreign exchange equals the reciprocal of the ratio of raw materials to GDP. 
output in the near future. A substitute for the CMEA in the form of a payments union or trade arrangement would certainly help. Given the financial and political problems of the former Soviet Union, it is not clear how well such an arrangement could have worked during 1991, but even maintaining some of the distorted bilateral arrangements during the transition could probably have softened the blow.

Given the magnitude of the output shock and the long time it takes for the productive system to respond to the new market signals, ways should be found to soften the blow to output and employment in the interim period, even if they may seem distorted from the long-run point of view. Government intervention in other forms is the likely alternative-extending credit and granting subsidies to ailing enterprises in a particular region or assigning larger budgetary allotments to unemployment relief.

\subsubsection{Exchange and Trade Policies}

The wisdom of applying the cold turkey solution to trade liberalization can be questioned, and moving in stages to current account convertibility through gradual reduction of tariff barriers may be a sensible policy (see Greene and Isard 1991; Tanzi 1991; and McKinnon 1991). There are strong arguments in favor of eliminating import licensing and quotas at one go, but there is no good inherent reason to move all at once to a zero, or very low, tariff. It is true that a gradualist strategy may lend itself to discretionary reversals by governments with low credibility. But, when it is credible, the strategy can mitigate the immediate output and employment costs while continuing to send the right price signals for long-term investment. If the strategy is to be credible, a commitment has to be made to a well-defined time path from a differentiated tariff structure toward a common low tariff within a few years (no more than, say, five). Examples of successful liberalizations that followed a preannounced gradualist path include the European Common Market, whose members agreed to a gradual mutual removal of tariffs in the $1950 \mathrm{~s}$ and $1960 \mathrm{~s},{ }^{18}$ and individual countries, such as Israel, whose trade liberalization in the $1960 \mathrm{~s}$ followed a gradualist path.

Even when the gradual path is chosen, the question remains whether initial tariffs should be differentiated across goods. To avoid political pressures, the policymaker may choose, for example, to differentiate only by general category of goods (raw materials, investment, and consumption goods) rather than by individual commodity or producer. In the next section, which takes up the fiscal balance, I argue in favor of a flat across-the-board tariff for purely fiscal reasons, until a value-added tax (VAT) is introduced.

A country that has opted for an ambitious trade reform from the start may not want to backtrack at a later stage because of loss of credibility, but it is a

18. In the case of the Common Market, it has taken quite a few years to phase out declining industries--e.g., coal and steel. 
lesson to bear in mind for future reference (e.g., in the states of the former Soviet Union), and, in fact, Poland eventually introduced a new and higher tariff structure in the second half of 1991. For some countries, however, the introduction of customs duties or tariffs may not be feasible, either because of the complete openness of their borders or because of the lack of necessary administrative capabilities. Unfortunately, that argument could also hold for any taxation, such as the VAT.

\subsubsection{Future Prospects}

Even when the output downturn is reversed, the experience of past reform and structural change (elsewhere as well as in Eastern Europe) shows evidence of substantial labor shedding and increasing unemployment, even as output rebounds.

Although public-sector output is collapsing, the small-scale private sector, especially in trade and services, seems to be thriving. However, given this sector's small initial base, even large increases at an early stage cannot affect the overall result unless the country starts off with a larger private sector to begin with. Poland may have been in this situation by 1992, when aggregate GDP started rising; at the time of writing, one can rely only on partial evidence and varying interpretations of the meaning of some numbers-for example, on unemployment. Although unemployment in Bulgaria had reached 10 percent, some have argued that there can be no serious unemployment problem if one cannot even find domestic help willing to work at the minimum wage; other observers have claimed that serious unemployment problems were emerging among the young. Both allegations may be correct, just as zero unemployment in Budapest or Prague can be entirely consistent with very serious unemployment in other heavily industrialized regions. It has also been argued that the Bulgarian state sector could sustain a major reduction in employment with minimum social upheaval because many of these workers could return to family farms or work on their own privately owned plots. For a country with excessive industrialization ( 60 percent of the labor force!), a shift to smallscale services, trade, and agriculture could be considered a move toward the correct long-run equilibrium composition of output.

For policy planners, the most relevant issue is the likelihood of immediate reversals in output and, especially, in the employment downturn because this outcome will determine the economic and, especially, the political sustainability of the initial set of stabilization policies.

\subsection{Can the Fiscal Balance Be Sustained?}

A key feature of the initial stabilization phase in all cases has been the balancing of the budget, primarily through a substantial, permanent cut in subsidies on goods and services, on the one hand, and an increase in expenditure on the social safety net, on the other. Given the existing tax revenue base, budget 
balance was assumed to be assured, as the figures for the respective programs show (see table 1.3). Keeping the budget in balance always requires careful scrutiny so that transitory changes can be isolated from permanent changes. Although the initial budget outcome seemed satisfactory in most countries, subsequent developments (usually starting in the second half of the first year) point to the emergence of serious problems for the second and third years of the programs. Let us consider the various causes and implications of these developments, starting with the experience of Poland.

At first glance, the Polish fiscal performance in 1990 turned out to be a surprising success, switching from a deficit of about 7 percent of GDP in 1989 to a surplus of about 3.5 percent. As Lane (1991) showed in detail, it was initially expected that the budget would follow a U-shaped profile over the year, with a shortfall in revenue in the first part of the year and an approximate balance over the year as a whole. In actual fact, the balance followed an inverted $U$ shape, with an increasing surplus in the first two quarters of 1990, turning into a drop in the surplus in the third quarter and a deficit in the fourth quarter of 1990. The estimates for 1991 showed a deficit of 7.2 percent for the year (compared to a planned approximate balance), with the prospect of an even larger deficit for 1992 if no corrective action were taken. ${ }^{19}$

The reasons for this outcome are important for future reference. The price surprise led to an unexpected deep fall in real wages resulting in larger-thanexpected profits and higher tax revenues. To these revenues was added a tax on capital gains on inventories and foreign currency deposits. Revenue from the latter was an entirely fortuitous one-time effect, resulting from an improper accounting for inflation. Once real wages rebounded and profits were squeezed, returns on the profit tax fell substantially. The profit squeeze has persisted into 1991 and is the more permanent effect of the liberalization process (see McKinnon 1991).

Czechoslovakia has gone through a similar process: a temporary surplus in the first few months of 1991 and an increasing deficit toward the end of the year. Similar problems are also emerging in Bulgaria, which differs from the others by not having had its enterprises' initial capital gains taxed away. Bulgaria showed a large increase in its deficit along with the output and import collapse. Romania's budget has stayed close to balance. In Hungary's budget, a deficit of close to 4 percent has emerged, despite the new VAT and income tax.

As was shown by Tanzi (1991), the East European countries typically enjoyed a profit tax revenue of about 15-20 percent of GDP, compared to a 3 percent average for the OECD. Table 1.5, based on Kopits (1991), gives an average breakdown of general government revenues and expenditures for 1985 in the five East European countries, compared with the former Soviet Union and the European Community. Although the cut in subsidies may account for

19. The deficit includes arrears to the nonbank public and unpaid obligations of the government to the domestic banking system. The cash deficit for 1991 is estimated at 5.7 percent. 
Table 1.5

Comparative Structure of General Government Budget, 1985 (\% of GDP/GNP)

\begin{tabular}{lccc}
\hline Budget Item & $\begin{array}{c}\text { Five East } \\
\text { European } \\
\text { Countries }^{\mathrm{a}}\end{array}$ & $\begin{array}{c}\text { Former } \\
\text { Soviet Union }\end{array}$ & $\begin{array}{c}\text { European } \\
\text { Community }\end{array}$ \\
\hline Total revenue: & 56 & 46 & 44 \\
$\quad$ Enterprise taxes & 17 & 18 & 4 \\
Personal income tax & 4 & 4 & 9 \\
Social security & 11 & 4 & 13 \\
Trade taxes & 2 & 6 & $\ldots$ \\
Expenditure taxes & 16 & 12 & 11 \\
Other & 6 & 2 & 76 \\
Total expenditures: & 55 & 56 & 16 \\
Current goods and services & 20 & 21 & 3 \\
Investment goods & 3 & 8 & 4 \\
Subsidies and transfers to enterprises & 19 & 18 & 15 \\
Transfers to households & 12 & 8 & 5 \\
Interest payments & 1 & $\ldots$ & 3 \\
Other & $\ldots$ & 1 & 46 \\
\hline
\end{tabular}

Source: Based on Kopits (1991, table 2).

anweighted average.

'Includes some investment transfers to enterprises.

a savings of 8-10 percent of GDP on the expenditure side, additional safety net expenditures and unemployment benefits are likely to expand as the process of structural change and labor shedding deepens. Further, the drop in enterprise profit taxes is likely to continue to exceed the net drop in expenditures.

A critical problem in all five countries is the transition from a relatively egalitarian and well-endowed social welfare network to a market system in which all the income and wealth distribution problems, unemployment risks, and other adverse social side effects of free capitalism suddenly emerge. Policymakers will face strong social and political pressures to continue the existing generous social security services and to correct for their recent erosion brought about by the sharp price increases. A large percentage of voters in these countries are pensioners. In Hungary, where 25 percent of the population are pensioners, male employees retire at 60 and females at 55. In Bulgaria pensioners are estimated to account for 35 percent of the voters, and the relative number of people receiving pensions in Poland has recently exceeded 40 percent. In Czechoslovakia, pressure may also come from the higher-than-average unemployment rate in the Slovak Republic (over 11 percent by the end of 1991 and rising, compared with a rate in the Czech Republic that was only 4 percent in 1991 and virtually zero a year earlier). Despite these pressures, there is room for streamlining the social welfare framework - for example, through privatization of some of the health services, charging for medication, and progressively taxing child allowance. 
One way or another, the net budget outcome is likely to be a permanent imbalance, unless output, sales, and the profit base rebound quickly or new taxes are imposed. Past experience shows that the introduction of a VAT takes at least three years in a country with reasonably organized enterprise accounts, and it is unlikely that this period can be effectively shortened. In the first year in which a VAT is introduced and existing taxes are replaced, there tends to be a reduction in revenues anyway. There is thus an urgent need to plan for temporary substitutes. For example, if trade liberalization were coupled from the beginning with a considerably larger tax on imports (even at a flat rate, say), the revenue from this source could have temporarily closed the gap, at least in part.

In the absence of a tax alternative, the pressure to balance the budget usually leads to expenditure cuts in areas where political opposition is light but the long-term economic cost is high, namely, investment in infrastructure (roads, communications). This is the one area where government intervention is usually essential and the positive externalities for the long-term growth of the private enterprise sector may be highest. There may be gradations in the urgency of the problem in the different countries (probably less crucial in Hungary and Czechoslovakia, more so in the other economies), but there is a minimum requirement in all of them, quite apart from the common need to cope with the inherited environmental damage.

This discussion leads to two important policy considerations. First, should some fiscal deficit be allowed for the interim period (until the tax reform is fully in place)? Second, should infrastructure investment be treated as part of regular government expenditure?

The answers to both questions should be considered in the context of each economy. The first and most important point is that, given the time-phasing nature of the problem, it is important that the annual budget plan should be embedded within a well-specified medium-term framework (of three years, at least). Ideally, the country should precommit itself to a budget trajectory for each of the coming years, with full budget balance to be regained within, at most, three years and the deficit in no year exceeding a certain percentage of GDP, say, 4 or 5 percent. The financing of this deficit should not come from the central bank ${ }^{20}$ but should be the responsibility of the ministry of finance, which must finance it from foreign or domestic private-sector borrowing, depending on the country's initial internal and external debt situation. A clear signal of precommitment along these lines may help prevent the adverse infla-

20. In theory, once there is positive real growth of GDP, the money supply could be increased, assuming stable velocity, at the rate of real growth. However, this decision had best be left to the discretion of monetary policy and an independent central bank and should not be built in as a potential source of deficit financing. Otherwise, political pressures on the central bank to accommodate a deficit may become ruinous. Recent developments in several of the countries in question bear out the importance of this caveat. 
tionary or crowding-out effects that a protracted deficit would otherwise engender.

Should infrastructure investment be treated differently? A textbook solution is to distinguish between the total deficit and the concept of government (dis)saving. The latter is more relevant for gauging the internal balance (although the former will still be important for financial planning). In this case, infrastructure investment could appear "below the line" as part of a separate capital budget that need not be financed by taxes. The objection to this "pure" solution is that it leaves the way open for potential abuse. Anything, so practical wisdom says, can be called investment, be it teachers' salaries, defense expenditures, or retraining for the unemployed. These loopholes can be closed, however, by adopting strict definitions of what constitutes direct government investment, limiting the percentage of GDP allowed (say, no more than an extra 3-5 percent), or not allowing for separation of budgets but raising the allowable total deficit by 1 percent, for example, for each 2 percent of planned additional infrastructure, with a total ceiling of no more than 5-6 percent. Earmarking specific foreign lending (e.g., by the World Bank) does, of course, ease matters.

There are no universal rules governing these considerations; they must of necessity be geared to each economy's specific risks or past record.

\subsection{What to Do with Bad Loan Portfolios and Enterprise Arrears?}

In all the East European countries, the previous economic and financial regimes left a legacy of bad enterprise debts that have continued to mount and have been stacked in the portfolios of the commercial banking system. The stringent stabilization programs, the credit crunch, and the collapse of the ruble zone export market have exacerbated the problem, as has the mounting interenterprise debt. In the early stages of stabilization, this problem was in most cases put off to one side. Unfortunately, the problem usually does not go away while waiting to be attended to but, on the contrary, gets worse and may interfere with the process of stabilization and structural adjustment. The existence of a large bad loan portfolio on banks' balance sheets is one of the causes of the persistent large gap between deposit and lending interest rates. It may also distort the relative creditworthiness of enterprises in a way that is not necessarily correlated with their potential profitability or long-run solvency in the new market environment.

In theory, the issue of bad loan portfolios is best dealt with up front in the context of a broader currency reform. When loan cleanups are included in the initial package, there is a better chance of avoiding the severe moral hazard problems that any such cleanups entail. In practice, no such provisions were included in the original packages. Even if they had been, the problem would have lingered on because much of the outstanding bad debt continued to accumulate in the poststabilization phase. When the problem is confronted, experi- 
ence has shown that extreme solutions should be avoided. One extreme is to leave the issue out of the central government's budgeting perspective altogether by "letting the banks deal with the problem," which seems to have been the prevailing view in Czechoslovakia at one point. If this approach is followed, quite apart from sending out the wrong price signals in the credit markets, it would eventually lead to a banking crisis, and the government would have to step in, and on a much larger scale than would be required otherwise. The other extreme solution is to yield to the cumulative political pressures from the debt-ridden enterprise sector and pass blanket debt-cancellation laws, which was the approach taken in Romania. Besides being indiscriminate, this solution invites serious moral hazard, reinforcing bad borrowing behavior by setting up the expectation that next time around enterprises will be bailed out again.

Outstanding bad debt is estimated at 15-20 percent of total bank debt in Hungary and Czechoslovakia and about 30-40 percent in Poland and Bulgaria. The ideal solution would be a credible, one-time cleanup of the books, with the government buying up debt through the commercial banks on a case-bycase basis, cleaning an enterprise only on the basis of a clear recovery plan, with strict conditionality and a strictly enforced budget constraint. ${ }^{21}$ However, this solution is probably unworkable for most of the countries and enterprises and banks in question, unless it were introduced during privatization as part of a sale bargain. In any event, those enterprises that can be identified as total failures should be phased out as quickly as possible. In Hungary, this procedure was recently used for the coal mining industry.

A major problem is the large number of enterprises whose future is uncertain but that have some potential for restructuring. Some policymakers in these countries are resisting across-the-board cleanups, citing an inherited lack of credibility with which the new governments have to contend. In their view, announcing in advance that something is to be done once and for all amounts to threatening with an unloaded gun. Only a slow process of rejections and tough bargaining will, according to this argument, instill the right discipline.

In general, the problem has been tackled through a gradual institutional and political bargaining process. In Hungary, for example, the government recently guaranteed 50 percent (Ft 10 billion) of the bad debts inherited by the banks from the previous regime. The remaining bad debt that has accumulated, mainly as a result of the CMEA collapse, will be provisioned by the banks over a three-year period, with the implicit understanding that it will be deducted from the annual profits for tax purposes (this implies an implicit participation

21. This procedure was followed in Israel in recent major debt-rescheduling schemes for the Histadrut-owned (trade union federation) industrial conglomerate (Koor) and in the settlements belonging to the Kibbutz movement. Both groups were in severe financial straits in the aftermath of the 1985 stabilization programs. The Kibbutz movement's cumulative debt had reached some 15 percent of total GDP before the financial restructuring plan was implemented. In another group, the Moshav (cooperative) movement, an earlier scheme had to be shelved because of noncompliance and political pressure, and a new one has yet to be instituted. 
of the state budget of 40 percent). This solution is politically attractive because it reduces the apparent profits of the banks (which have recently been exorbitant, given the large interest rate margins) while appearing to conceal the implicit cost to the budget. In Czechoslovakia, the government decided to allow the National Property Funds, the recipients of the proceeds from privatization, to issue Kčs 50 billion in bonds to be used to write off old enterprise debt and to provide a direct capital injection to the banks. This solution actually seems to be working (see below), especially since Czechoslovakia's internal debt is small. It remains to be seen whether Czechoslovakia and Bulgaria can also introduce a bank provisioning and tax participation scheme similar to the one adopted in Hungary.

Another major problem is how to prevent enterprises from continuing to borrow to survive rather than adjusting. Recapitalizing the banks and letting them handle the problem would seem to be the best policy, provided that the banks are equipped to make the proper economic analysis and are able to take into account the interests of the bond issuers, namely, the government or the taxpayers (who implicitly cover the tax losses). Unfortunately, the financial interests of commercial banks and the long-run economic viability of the enterprise do not necessarily coincide; ideally, the existing owner of the asset, namely, the state, should participate in the process. This is part of the more general problem of enterprise control in the transition period (see the next section) and is further compounded by the fact that the commercial banking system itself is not yet financially independent of the central bank, leaving part of the quasi-fiscal deficit open ended.

How should the public financing of bank capitalization and enterprise restructuring be treated? If this type of public expenditure takes the form of a once-and-for-all stock adjustment, it should not be reckoned as part of the regular tax-financed budget. Rather, it should be included as part of the privatization accounts (as is done by the Treuhandanstalt in East Germany or, implicitly, in the recent Czechoslovak financial injection). Even if there is an initial net debt position, it could be financed by the issue of domestic bonds and/ or external financial aid. Alternatively, it could be included in a broader capital account budget from which infrastructure investment could also be financed. To be credible, a one-time stock adjustment should not be perceived as a permanent rise in the money and credit growth rates.

Finally, it is essential that enterprises are given the right signal--that financial rescheduling is a one-time conditional act, not a precedent.

\subsection{Privatization of Large State-Owned Enterprises-What to Do during the (Long) Transition?}

In all five East European countries, the privatization of (mainly small-scale) trade and services enterprises has moved briskly, but it is at a virtual standstill for large-scale enterprises, primarily in the manufacturing sector. The reasons 
for the delay have been legal (restitution problems in Czechoslovakia), political (bad experiences with instant privatization in Hungary and Poland), or practical (lack of foreign or domestic investors). Even with the advanced voucher scheme being implemented in Czechoslovakia, it is not yet clear how a new, workable corporate control will emerge. It is clear that in all countries there will be a prolonged interim period during which the state will continue to own a considerable portion of the enterprise sector.

In privatization, as in loan cleanups, extreme solutions (completely discard or continue to embrace the past regime) are not workable and certainly not the optimal solution. The problem is how to instill market-oriented behavior in management and workers without unduly delaying the privatization stage. It appears that this problem has not been systematically addressed in any of the countries.

In Hungary, an attempt has been made to learn from the failure of the previous government's "spontaneous privatization" episode. The new Law on Economic Transformation moves the state-owned enterprises (SOEs) out of the jurisdiction of enterprise councils and gives them company status, under the aegis of the State Property Agency (SPA). In the transition period, the state becomes the legal owner as audited balance sheets and a board of directors are introduced. Supervision of management is partly subcontracted to approved advisory agencies, which become the agents of the SPA.

Much of the Hungarian privatization has taken the form of "selfprivatization," whereby a manager looks for potential buyers, who then must be approved by the SPA or its accredited consulting firms. The process is obviously a slow one. The Czechoslovak government, in contrast, seems to have opted for speedy privatization since only the new owners will be in a position to do what is good for the firm. As a result, no systematic thought has been given to how the enterprises in the so-called no-man's land are to be controlled. Although the view is understandable, ignoring the problem does not help since pressure is mounting for subsidies or cheap credit for enterprises in depressed regions.

Giving in to these pressures could result in SOEs staying in state hands forever. Unfortunately, there seems to be no escape from these halfway policies, unless the authorities are willing to take the line that what cannot be privatized instantaneously had better be scrapped. This option, however, makes little economic sense from a medium-run point of view since a sizable amount of industrial product may be made marketable after marginal investments have been made in physical and/or human capital, especially on the marketing side. Moreover, because of the huge potential unemployment problem (with employment in SOEs anywhere between 30 and 50 percent of the labor force), wholesale scrapping is not very likely to be feasible.

In Poland, commercialization as an intermediate step was envisaged as important since it was more likely to free managers from the control of the workers' councils. Managerial compensation is important to avoid decapitalization 
of firms. Such compensation could be given, at least in part, by long-maturity stock options or by including a longer-term profit share in the manager's contract. A compelling alternative argument, at least for the Polish case (see Dabrowski, Federowicz, and Levitas 1991), is that the power of the workers' councils is too important a legacy from the Communist regime to be easily dissipated. According to this view, the only way to resolve the political stalemate between the workers' councils and the state is mass privatization through giveaway schemes in which the present stakeholders in the enterprise, namely, the workers' councils and the managers, will be the major beneficiaries. This would be a form of controlled spontaneous privatization.

The variety of experience across countries suggests that there may not be one best way of resolving the privatization issue and that each country must choose the one that best fits its political and social framework. But, no matter which strategy each country adopts, it is important that it be transparent, sending clear signals to investors, managers, and workers, so as to minimize uncertainty in the transition period. Also, policy framers must not forget that macroeconomic policies alone can achieve only so much and that micro management policies should be integrated into the general policy framework right from the start as well as throughout the program. Privatization is one part of the reform process where the integration of macro and micro policy is essential.

\subsection{Concluding Remarks}

This discussion of the recent East European experience with stabilization points to broad common denominators in the five countries considered here as well as with countries elsewhere. The sharp stabilization approach applies more or less generally, while any differences across countries originate in the varying ability to control the budget or the amount of credit or wage policy rather than in the underlying conceptual macroeconomic framework. The greatest differences across countries are also the micro foundations of each economy, such as in ownership rights and financial accountability-which have also proved most resistant to change. The general lesson to be learned here is that, from the start, the policy reform package has to put even greater emphasis on implementation of the institutions and rules of behavior for the micro units. Otherwise, the stabilization part of the reform could unravel.

Another related issue is the perceived role of government in the transition from a centrally planned to a market economy. In the old days, communism was often viewed from the outside in highly simplified terms - a minutely detailed central plan and an omnipotent government. Likewise, today, capitalism is viewed simplistically by those who would like to embrace it as a well-oiled system consisting only of private property ownership and pure laissez-faire and self-adjusting market mechanisms, requiring no government interference. However, market failures often occur in the most laissez-faire economies (e.g., in financial markets), and governments have to intervene in the microeconomy. 
Thus, a hands-off policy during the transition from a centrally planned to a market economy would be most inappropriate. The temptation to resort to the old mistakes under central planning may be strong - for example, in the process of restructuring - but that possibility should not be used as an argument against any government intervention during the transition period. If the necessity for intervention is not acknowledged and guidelines regulating its application and defining its purpose are not established, there will be intervention in practice anyway, but, without an overall view of its scope, direction, and implications, intervention will be haphazard and could involve costs that would breach budget constraints and threaten macroeconomic stability.

This discussion has concentrated mainly on issues common to the five East European countries during the past two years. As time passes, the differences among these countries are likely to become more important from a policy perspective, as has usually been the experience of other countries undergoing stabilization and structural reform.

One issue on which economists cannot be of much help is the internal politics of reform. The external observer is struck by the apparent universal acceptance of the drastic changes that have taken place so far, despite the sharp real wage cuts, the fall in living standards, and the rise in unemployment. Although it can be reasonably argued that the official statistics do not really capture reality because of statistical biases, incorrect coverage, and so on, it is also true that numbers, even if inaccurate, are used in the political marketplace (e.g., the consumer price index is used in the wage bargaining process, whether formally or informally). Some recent attempted strikes in Czechoslovakia ran into public opposition, and the policy stance of the government appears to be well understood by the public at large. The government in Bulgaria, with all its difficulties, apparently seems to have public support. In Hungary, however, there seemed to be a contrast between the apparent success of macro policies and the public's negative perception of them, as if the government has been unsuccessful in selling its policy product.

The experience with reforms both elsewhere and across countries in Eastern Europe points to the paramount importance of policymakers being able not only to spell out government strategies in detail and in terms that can be widely understood but also to sell their product to the public. The impending internal social problems in all the countries will no doubt put all the reform efforts to a serious test, as political democratization proceeds and the possibility of bliss recedes. The social element is no doubt the biggest imponderable in each of the countries: what, if anything, can ensure the maintenance of the social consensus over the period of the reform program and its political sustainability in the near future? As one observer has asked, "Are they, in return for true freedom, prepared to give up bread lines for unemployment lines?" 22 The 1991-92 
postelection developments in Poland and the separatist movement in Czechoslovakia do not bode well, but in this area, as with many others surveyed in this paper, it is probably much too early to tell.

\section{References}

Aghevli, Bijan G., Eduardo Borensztein, and Tessa van der Willigen. Stabilization and structural reform in the Czech and Slovak Federal Republic: First stage. Occasional Paper no. 92. Washington, D.C.: International Monetary Fund, March.

Boote, Anthony R, and Janos Somogyi. 1991. Economic reform in Hungary since 1968. Occasional Paper no. 83. Washington, D.C.: International Monetary Fund, July.

Bruno, Michael. 1993. Crisis, stabilization and economic reform: Therapy by consensus. Oxford: Oxford University Press.

Bruno, Michael, and Jeffrey Sachs. 1985. Economics of worldwide stagflation. Cambridge, Mass.: Harvard University Press.

Calvo, Guillermo A., and Fabrizio Coricelli. 1992. Stabilizing a previously centrally planned economy: Poland 1990. Economic Policy, no. 14 (April): 176-226.

Dabrowski, J. M., M. Federowicz, and A. Levitas. 1991. Polish state enterprises and the properties of performance: Stabilization, marketization, privatization. Politics and Society 19 (December): 403-37.

Demekas, Dimitri G., and Mohsin S. Khan. 1991. The Romanian economic reform program. Occasional Paper no. 89. Washington, D.C.: International Monetary Fund, November.

Fischer, Stanley, and Alan Gelb. 1990. Issues in socialist economy reform. Working Paper Series Discussion Paper no. 565. Washington, D.C.: World Bank.

Greene, Joshua E., and Peter Isard. 1991. Currency convertibility and the transformation of centrally planned economies. Occasional Paper no. 81. Washington, D.C.: International Monetary Fund, June.

Institute for Comparative Economic Studies (ICES). 1990. COMECON data. Vienna.

Klaus, Vaclav. 1991. Dismantling socialism: A preliminary report. Occasional Paper no. 35. Sydney: Centre for Independent Study.

Kopits, George. 1991. Fiscal reform in European economies in transition. Working Paper no. 91/43. Washington, D.C.: International Monetary Fund, April.

Lane, Timothy D. 1991. Inflation stabilization and economic transformation in Poland: The first year. Working Paper no. 91/70. Washington, D.C.: International Monetary Fund, July.

Lipton, David, and Jeffrey Sachs. 1991. Creating a market economy in Eastern Europe: The case of Poland. Brookings Papers on Economic Activity, no. 1:75-147.

McKinnon, Ronald I. 1991. Taxation, money, and credit in liberalizing socialist economies. Washington, D.C.: Institute for Policy Reform, November.

Organization for Economic Cooperation and Development (OECD). 1992. Economic survey for Hungary, 1991. Paris.

Rodrik, Dani. 1992. Making sense of Soviet trade shock in Eastern Europe: A framework and some estimates. Working Paper no. 4112. Cambridge, Mass.: NBER, June.

Solimano, Andres. 1991. The economies of Central and Eastern Europe: An historical and international perspective. In Reforming Central and Eastern European econo- 
mies, ed. Vittorio Corbo, Fabrizio Coricelli, and Jan Bossak. Washington, D.C.: World Bank.

Tanzi, Vito. 1991. Tax reform in economies in transition: A brief introduction to the main issues. Working Paper no. 91/23. Washington, D.C.: International Monetary Fund, March.

World Bank. 1991. World development report. Washington, D.C. 
This Page Intentionally Left Blank 